\title{
Cattle farmers: profile and speech content analysis while undergoing training to adopt artificial insemination in Goiás State, Brazil
}

\author{
João Maurício Lucas Gordo ${ }^{1,2}$, Marcelo Corrêa da Silva, ${ }^{2,3}$, Gianice de Almeida Solano ${ }^{4}$, \\ Fernando Brito Lopes ${ }^{2,3}$, Marcos Fernando Oliveira e Costa ${ }^{2,3}$, Francisco Eduardo de Castro \\ Rocha $^{4}$, Maria Clorinda Soares Fioravanti ${ }^{1}$, José Robson Bezerra Sereno ${ }^{4}$

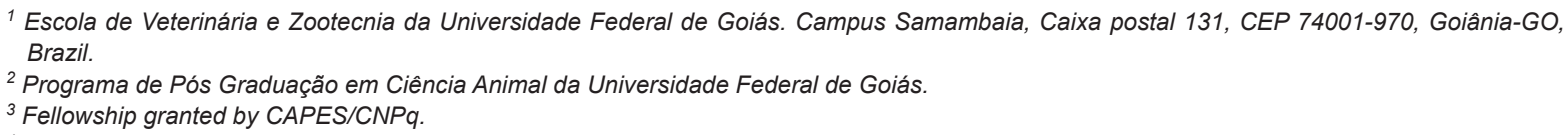

ABSTRACT - This study was undertaken to verify major issues present in the discourse of cattle farmers when discussing the use of artificial insemination (AI). Seventy-one beef and dairy cattle farmers in the state of Goiás, Brazil, were interviewed using semi-structured questionnaires during AI training courses in 2010 and 2011. Data analyses were done using the classic method of textual speech content analysis, performing the pre-analytical, analytical and inferential stages. The written questions were separated in elementary context units (ECU) and sorted into similar thematic groups. These groups originated categories and subcategories, which were nominated based on an a posteriori criteria. Overall, personal motivation was the main issue characterizing discourse by farmers about adoption of AI. This motivation stems from the strong points (highlights) and positive expectations AI offers. The positive expectations were mainly related to perceptions of farmers of animal phenotype improvement rather than to the financial features of cattle production. Basic necessity was the second major issue, with emphasis on work force, infrastructure and animal handling, followed by social influence, with eminence of the institutions and people involved with AI and with the everyday life of cattle farmers. The little emphasis on human resource management and on the use of scientific knowledge may have affected the impact of AI over the years, explaining discreet indices of adoption of $\mathrm{AI}$ in Brazil.

Key Words: animal reproduction, biotechnology, discourse analysis, social psychology

\section{Introduction}

The use of artificial insemination (AI) in Brazil increased $39.35 \%$ in beef cattle breeds and $72.41 \%$ in dairy breeds between 2000 and 2010 (ASBIA, 2010). In this country, the use of AI in cattle production increased $13.69 \%$ between 2009 and 2010. In 2009, nine million doses of bovine semen were commercialized. Despite the impressive numbers, only $7 \%$ of the cows already in reproductive age were artificially inseminated in this year, with $93 \%$ conceived in natural mating systems (ASBIA, 2010).

Many factors can influence AI adoption. Most agricultural and husbandry technology studies point out poor access to markets and institutional guidance (Feder \& Umali, 1993), public policies, information and profit guarantees (Enyong et al., 1999), social inequality and dominance of traditional handling (Souza, 1997; Barbosa \& Machado, 2008), lack of organized mating systems (TorresJúnior et al., 2009), technology costs and little capacitated labor force (Rodrigues et al., 2008; Sá Filho et al., 2008; Pfeifer, 2008).

However, the discussion and understanding of technology adoption rates require specific methods and should encompass more than personal opinions of academics to be sufficient (Dagnino, 2009). Perceptions of farmers, individual attitudes and general behavior can be as important as the technological issues during agribusiness and rural development projects (Rocha et al., 2008a).

In Brazil, preferences during events of technology adoption have not yet been investigated enough in animal production, being more frequent in anthropologic, psychological and sociological sciences (Rocha et al., 2008a; Rocha et al., 2008c). This could indicate that in animal production science little emphasis has been given to clients of farm technologies. Understanding perceptions of farmers (Jensen et al., 2007) can help research and rural extension institutions to build up strategies and optimize technology transfer. 
This study was developed as an attempt to propose guidelines to all institutions involved with cattle breeding in Brazil. More specifically, this research was carried out to characterize the profile of cattle farmers in the state of Goiás undergoing training and entering the adoption process of AI. Also, to verify and organize the main topics that appear when these farmers answer questions concerning their concept, influences and intention to adopt AI.

\section{Material and Methods}

The methodology used in this research was based on descriptive, exploratory, quantitative and qualitative approaches, including a non probabilistic technique for sampling. Two questionnaires were developed during a multidisciplinary meeting. Seventy-one cattle farmers (dairy and beef cattle) were interviewed across 30 municipalities of the state of Goiás. The first questionnaire contained biodemographic information; the second contained concepts concerned, points of view, influences and expectations related to AI. For standardization, the conventional method of AI and the more recent fixed time method were considered the same. The interviews were conducted in 2010 and 2011 while farmers attended training courses offered by the local Governmental Rural Extension Company of Goiás (EMATER-GO), and by the Agricultural Federation of the State of Goiás (FAEG) through the National Service of Rural Apprenticeship (SENAR). The questionnaires were applied at the end of the training courses by technical consultants. In each course, all farmers wrote down the answers simultaneously and individually.

Biodemographic information was analyzed using descriptive statistics in Microsoft Excel $^{\circledR}$ spreadsheets. Speech information was analyzed using the classical model of context analysis (Bardin, 2004), defined as a mix of quantitative and qualitative methods, where written answers of the questionnaires are starting points for speech evaluation (Franco, 2007a).

Data analyses were divided in three stages: pre-analysis, analysis and the inferential stage. In the first stage, the answers were written in Excel spreadsheets (transcription) and a data set was built up (corpus constitution) so that three technicians could simultaneously carry out a first reading and evaluation process, discarding words and sentences with no apparent meaning. Sequentially, the questions were deleted and the answers were grouped up, originating a new spreadsheet. At this moment, an attentive and repetitive reading period took place (corpus impregnation) so the inferential stage could begin.
Inferential analysis began with the "clipping of the corpus" (corpus fragmentation) using the symbol "/", which separates words and sentences and originates the elementary context units (ECU) (corpus codification). This means that using a mark symbol, all full sentences that built up the corpus were divided into smaller phrases or even in single words that represented a specific or very succinct idea (ECU), i.e., "One has to have good genetics so that AI works / and to confirm that AI will help us we have to modify a lot of our handling activities/ but sometimes the investments required are too expensive/'. After the corpus was fully separated into ECU it was considered to be codified. Sentences with meanings of opposition, adversity, complementarity or deductive sentences were maintained in the same ECU. Sentences with confirmative or reiteration meanings were clipped into different ECU. Information judged by the referees to be passable of omission was substituted by the symbol “...”. Subsequently, the fragments were agglomerated into similar thematic groups, originating categories, i.e.: “/... we need more instruction/... intensify technical support.../ ...rural extension.../ ...we need to know how to choose the correct semen/...too much delay to deliver semen.../... extension services... P".

When convenient, categories were divided into secondary and even tertiary subcategories (corpus categorization), allowing for quantification $(\%, f)$ of ECU in all structures and substructures.

In the final stage of data analysis (inferential stage) the categories were sorted out (category operation) and discussed collaboratively among the referees. Referee interpretation was based on theoretical marks of rural development and livestock science, casuistic observations collected during the interviews, and skills acquired during methodological training. All proceedings were handled so that the nomination or "category baptism" was appointed in the final stage of analysis. This means that first the ECU were sorted according to similarity, then the arranged ECU originated categories and subcategories and finally the categories were named according to their content (a posteriori category nomination).

\section{Results and Discussion}

Most farmers were male family members (92\%) with a broad range of age, level of education, and experience in cattle production. Income also varied amongst families; it was pluriactive and financially dependent on farm activities. Seventy-five percent of the farmers had over eight years of cattle raising experience. Farmers with AI experience formed two distinct groups: 1) $54 \%$ used any reproductive 
biotechnique; 2) $46 \%$ did not use any. Most farmers of the first group (69\%) used conventional AI, other than the fixed-time AI method (FTAI) (13\%), and $18 \%$ of the farmers declared to use AI as well as FTAI. Breeding season administration was not practiced by $92 \%$ of the farmers. This result is worrisome because this practice is useful to organize birth dates, productivity increase and sanitary and general handling activities (Torres-Júnior et al., 2009). This result could be due to sample effect considering that this strategy is more usual in beef than dairy cattle production. Most farmers had between 31 and 100 ha of land (39\%) and between 31 and 90 adult cows (46\%). Average farm extension was 167 ha $(11980 / 72)$ and average cows per farm was $112(7725 / 69)$.

The corpus was made up by $1.167 \mathrm{ECU} ; 11 \%$ of them were discarded. Three main categories were originated from corpus analysis: 1) Basic necessities for AI adoption, (32.69\% of all ECU); 2) Personal motivation for AI adoption (43.85\% of all ECU); and 3) Social influence for AI adoption (23.46\% of all ECU).

Cattle farmers emphasized labor quality and labor availability to work inside the farm and in all other segments of the production chain as basic necessities for AI adoption (39.11\%) (Table 1). This includes rural workers, suppliers and retailers. Emphasis on labor could be due to the fact that AI involves not only semen delivery and deposition but also the everyday observation of estrus manifestation (Pfeifer, 2008); the success of AI programs is often attributed to labor force (Rodrigues et al., 2008; Sá Filho et al., 2008). Even in regions of Brazil where productivity is higher, as in the state of Goiás, availability and quality of work force in rural areas is a frequent and repetitive issue (Chase, 1999; Schaffner, 1993).

As a prerequisite for AI adoption, farmers often emphasized the necessity of modifying and intensifying dedication in feeding, reproductive and sanitary handling. The necessity of genetic and phenotypic features, such as the productive aptitude of their herds (herd type) was of little concern. Without basic modifications within the farm, AI will probably be ineffective, due to reasons like low body condition scores. However, the point of view of farmers contrasts with disproportions between rapid results of genetic breeding programs and extremely low technical levels of breeding systems, which has been associated with physiological stress, herd infertility and productivity reduction (Dobson et al., 2008). Infrastructure investments such as weight scales, pastures and containment facilities are important features in cattle farming and were pointed out by the farmers as important prerequisites.

The necessity to sensitize and make everyone involved with AI technology aware is not a frequent issue in the discourse of cattle farmers (Table 1). This is a matter of concern because miscommunications can lead to mistakes and lack of achievements. Client satisfaction is very dependent on whether a technology can power up farm competiveness or not (Euclides Filho et al., 2002) and human resource management should not be disregarded. Russi (2008) verified that a low productivity rate is a common cause to dismiss inseminators, but most resignation and penalization of farm employees are due to lack of responsibility or interpersonal trouble. If the satisfaction of landowners is related to technology repercussion, it is important to consider that farm managers have important roles on $\mathrm{AI}$ results and that there is more to consider besides technological or farm infrastructure topics. Russi (2008) verified that satisfaction and welfare of farm managers are important features and may significantly affect the outcome of AI programs. The little emphasis on human resource management possibly suggests that good productive participative communication principles are more frequent in production lines of the industry sector than in farm levels. Another hypothesis is that the crescent demand for reproductive biotechnologies is related to outsourcing of estrus synchronization and guarantees of pregnancy rates

Table 1 - Arrangement and percentage of subcategories and similar elementary context units obtained from the speech of farmers undergoing training and adoption of AI in Goiás State, Brazil (Category 1)

\begin{tabular}{|c|c|c|c|c|}
\hline \multicolumn{5}{|c|}{ Category 1: Basic necessities for adoption of AI } \\
\hline Primary subcategories & Secondary subcategories & Observed frequency & Relative frequency & $\%$ Total \\
\hline \multirow[t]{2}{*}{ Work force } & Inside and outside the farm & 96 & 28.23 & \multirow{5}{*}{32.69} \\
\hline & Related to service providers & 37 & 10.88 & \\
\hline \multirow[t]{3}{*}{ Actions in the production system } & Human resource management & 17 & 5.00 & \\
\hline & Animal handling & 68 & 20.00 & \\
\hline & Herd type & 20 & 5.88 & \\
\hline Infrastructure, facilities and instruments & & 102 & 29.99 & \\
\hline Subtotal & & 340 & 100 & \\
\hline
\end{tabular}

$\mathrm{AI}$ - artificial insemination. 
by private companies (Torres-Júnior et al., 2009). This simplifies participation of farmers in reproductive handling and could explain minor preoccupation with human resources management. Private corporation services will probably become more frequent in the Brazilian cattle farming agribusiness, and the modernization of transport and communication services are important factors that enable innovation in rural areas of this country (Alves, 2006).

Personal motivation for AI adoption is mainly related to positive expectations that farmers have considering potential results of $\mathrm{AI}(65.55 \%)$ (Table 2). This motivation can be understood by financial improvements $(22.36 \%)$ or cattle quality improvement (43.19\%), considering quantitative and qualitative improvements of economic and animal components, respectively (Table 2).

Enyong et al. (1999) and Pfeifer (2008) reported that profit potentials and the cost of a technology are the main bottlenecks for adoption of many biotechniques. However, for AI, improvements in the animal component are more motivating for farmers than potential economic upturns. Interactions between biological and economic factors and the influence of these aspects in cattle production have been reviewed by Barber (1983). Animal biotype may be related to economic features in some way, but phenotype improvement is the first reason that motivates the adoption of AI in Goiás State. In addition, motivation related to AI adoption is not necessarily based on quantitative aspects, profitability and productive traits (19.73\%); subjective perceptions in qualitative improvements are more emphasized in the discourse of farmers (45.82\%). This corroborates the results found by Russi (2008), who verified that investments to improve welfare of employees was more effective than additional payments for calving rates. These results indicate that not only productive and economic aspects should be considered in cattle production and technology adoption in this region and that much of the cattle production in Goiás is still based on traditional family farming rather than modern agribusiness (patronal). Sustainability should be better considered, in accordance with Thibier (2005), Salem \& Khemire (2008) and Dagnino (2009) referring to AI and rural development projects and to Enyong et al. (1999), considering qualitative concepts and values.

Farmers emphasized the strong points related to the use of AI, such as potential motivation sources for adoption (Table 2). This is understood as possibilities that AI provides to choose a specific bull, birth date prediction and other monitoring improvement. Many ECU in this primary subcategory were information referring to bulls. The concern of farmers for bulls could be explained revising semen commercialization statistics in Brazil, in which $93 \%$ of the cows are conceived in natural mating systems. Villela (2010) stated that excessive use of the same bull in consecutive generations is a great limitation for inbreeding control and genetic improvement in Brazil.

Sanitary improvements expected with AI are not strong sources to motivate its adoption by farmers (Table 2). The percentage was considered low because the interviews during final stages of the training courses and topics concerning sanitary benefits had already been revealed. This could be due to cultural circumstances, where commonplace medication overrides precaution policies and concepts.

Perceptions and experiences had little emphasis on the discourse of farmers, maybe because the interviews happened when farmers were still undergoing training and were in initial stages of the overall adoption process. In these terms, adoption is considered a group of behaviors correlated to familiarization, experience and farmer beliefs (Rocha et al., 2008a,b).

Social influence is composed of opinion makers involved in the AI adoption process (Table 3). The major influences on the social level were built up by public and

Table 2 - Arrangement and percentage of subcategories and similar elementary context units obtained from the speech of farmers undergoing training and adoption of AI in Goiás State, Brazil (Category 2)

\begin{tabular}{|c|c|c|c|c|c|}
\hline Primary subcategories & Secondary subcategories & Tertiary subcategories & Observed frequency & Relative frequency & $\%$ Total \\
\hline \multicolumn{3}{|c|}{ Strong points related to the use of AI } & 107 & 23.46 & \multirow{6}{*}{43.85} \\
\hline \multirow{5}{*}{$\begin{array}{l}\text { Positive expectations } \\
\text { concerning result } \\
\text { prospection }\end{array}$} & \multirow{2}{*}{$\begin{array}{l}\text { Improvement of } \\
\text { quantitative indicators }\end{array}$} & Animal component & 34 & 7.45 & \\
\hline & & Economic component & 56 & 12.28 & \\
\hline & \multirow{2}{*}{$\begin{array}{l}\text { Improvement of qualitative } \\
\text { indicators }\end{array}$} & Animal component & 163 & 35.74 & \\
\hline & & Economic component & 46 & 10.08 & \\
\hline & \multicolumn{2}{|c|}{ Sanitary improvements } & 31 & 6.79 & \\
\hline \multicolumn{3}{|c|}{ Perceptions and experiences } & 19 & 4.16 & \\
\hline \multicolumn{3}{|c|}{ Subtotal } & 456 & 100 & \\
\hline
\end{tabular}

AI - artificial insemination. 
private institutions and by people related to the family or the rural production scenario. Next, it was followed by the influence of instructors and technicians, and in a lower magnitude, by mass communication mechanisms (Table 3).

As verified by Zuin et al. (2011), great influence of successful neighbors and other reference cattle breeders may result in the phenomenon of "diffusion based on jealousness", where techniques useful to some farmers become more demanded by others.

The discreetness of literature as a source of social influence (Table 3) can be due to little amount of publications with a proper layout for cattle farmers, due to access issues or even a non-reading culture profile. One hypothesis is that the pluriactive characteristic of the interviewed group results in shared priorities, meaning more discreet and equally distributed investments in general, little use of scientific knowledge and generally low professional standards. According to Rogers (1971), mass communication channels are more efficient when developing client understanding; interpersonal communication is more effective during convincement, awareness and to provoke attitude modification by farmers. This could be the main explanation for the results verified in category 3 (Table 3 ).

An overview of all three categories demonstrates that the structures and substructures contain parts of a discourse that range a greater ambit besides technological or economic features. These structures were also built up by biological, environmental and social issues, which according to Franco (2007b) represents category diversification and is a result of choosing the a posteriori method to nominate the categories and subcategories.

Personal motivation (category 2) is the main topic in the speech of cattle farmers that are undergoing training and the adoption process of AI in the state of Goiás. This motivation is related to highlights and positive expectations related to the use of AI. Most expectations manifested by the farmers are directed to animal phenotype rather than financial aspects. Basic necessities for AI adoption (category 1) are the second major topic in the discourse of farmers, with emphasis on work force, infrastructure and animal handling, followed by social influence (category 3), with emphasis on institutions and people involved with AI and with the everyday life of cattle farmers.

If increasing rates of $\mathrm{AI}$ is a target in the Brazilian cattle agribusiness, then the information of this research may subsidize extension and technological interventions in the state of Goiás that seek livestock industry competiveness and the welfare and satisfaction of cattle farmers.

Table 3 - Arrangement and percentage of subcategories and similar elementary context units obtained from the speech of farmers undergoing training and adoption of AI in Goiás State, Brazil (Category 3)

\begin{tabular}{|c|c|c|c|c|}
\hline Primary subcategories & Secondary subcategories & Observed frequency & Relative frequency & $\%$ Total \\
\hline \multirow{5}{*}{$\begin{array}{l}\text { Opinion makers for cattle farmers in } \\
\text { the adoption process of AI }\end{array}$} & Absence of opinion makers & 44 & 18.03 & \multirow{5}{*}{23.46} \\
\hline & Public and private institutions & 102 & 41.80 & \\
\hline & $\begin{array}{l}\text { Family, friends, neighbor employees } \\
\text { and other breeders }\end{array}$ & 56 & 22.95 & \\
\hline & Teachers, veterinaries, technicians & 31 & 12.70 & \\
\hline & Digital and printed media & 11 & 4.50 & \\
\hline Subtotal & & 244 & 100 & \\
\hline
\end{tabular}

AI - artificial insemination.

\section{Conclusions}

The profile of farmers undergoing training and adoption of AI in the state of Goiás is heterogeneous. Extension policies must consider specificities among farms and farmers. In a decreasing order, sources of personal motivation, basic necessities and sources of social influence for AI adoption are the major issues in the discourse of cattle farmers. Promising benefits from AI and the idea of phenotypical improvement are major motivation topics.
Infrastructure and work force investments in all sectors of the production chain are the most frequent issues of basic needs for AI adoption. Sources of social influence are also important in the adoption process and are represented mainly by the institutions that research, sell or teach the use of AI technology, followed by the influence of friends, family and other cattle breeders. Little emphasis on human resource management and on the use of scientific knowledge may have affected the impact of AI over the years, explaining discreet indices of adoption of AI in Brazil. 


\section{References}

ALVES, E. Migração rural-urbana, agricultura familiar e novas tecnologias: coletânea de artigos revistos. Brasília: Embrapa Informação Tecnológica, 2006. 181p.

ASSOCIAÇÃO BRASILEIRA DE INSEMINAÇÃO ARTIFICIAL - ASBIA. Relatório estatístico de importação, exportação e comercialização de sêmen. 2010. Available at: <http://www. asbia.org.br/novo/upload/mercado/relatorio2010.pdf.> Accessed on: July 15, 2011.

BARBER, K.A. Maximizing the impact of dairy and beef bulls through breeding technology. Journal of Dairy Science, v.66, p.2661-2671, 1983.

BARBOSA, R.T.; MACHADO, R. Panorama da inseminação artificial em bovinos. Documentos, n. 84. São Carlos: Embrapa Pecuária Sudeste, 2008 Available at: <http://www.cppse.embrapa.br/ 080servicos/070publicacaogratuita/documentos/documentos 84 . $\mathrm{pdf} / \mathrm{view}>$ Accessed on: July 26, 2010.

BARDIN, L. Análise de conteúdo. 3.ed. Lisboa: Edições 70, 2004. 223p.

CHASE, J. Trapped workers, urban freedoms and labor control in Brazilian agriculture: Evidence from southwest Goiás. Journal of Rural Studies, v.15, p.201-220, 1999.

DAGNINO, R.P. Tecnologia social: Ferramenta para construir outra sociedade. Campinas: Unicamp, 2009. 183p.

DOBSON, H.; WALKER, S.L.; MORRIS, M.J. et al. Why is it getting more difficult to successfully artificially inseminate dairy cows? Animal, v.2, p.1104-1111, 2008.

ENYONG,L.A.;DEBRAH, S.K.;BATIONO,A.Farmers'perceptions and attitudes towards introduced soil-fertility: enhancing technologies in western Africa. Nutrient Cycling in Agroecosystems, v.53, p.177-187, 1999 .

EUCLIDES FILHO, K.; CORRÊA, E.S.; EUCLIDES, V.P.B. Boas práticas na produção de bovinos de corte. Documentos, n. 129. Campo Grande: Embrapa Gado de Corte, 2002. Available at: $<$ http://www.cnpgc.embrapa.br/publicacoes/doc/doc_pdf/Doc129.pdf $>$ Accessed on: Aug. 20, 2010.

FEDER, G.; UMALI, D.L. The adoption of agricultural innovations: a review. Technological Forecasting and Social Change, v.43, p.215-239, 1993.

FRANCO, M.L.P.B. Análise de conteúdo. Brasília: Líber Livro Editora, 2007a. v.6, p.69-78.

FRANCO, M.L.P.B. As categorias de análise. In:__. Análise de conteúdo. Brasília: Líber Livro Editora, 2007b. cap.6, p.59-68.

JENSEN, M.B.; JOHNSON, B.; LORENZ, E. et al. Forms of knowledge and modes of innovation. Research Policy, v.36, p.680-693, 2007.

PFEIFER, L.F.M. Efeito da progesterona e PGF2 alfa na indução da puberdade e fertilidade em fêmeas bovinas de corte. 2008. 80f. Tese (Doutorado em Zootecnia) - Universidade Federal de Pelotas, Pelotas.

ROCHA, F.E.C.; ALBUQUERQUE, F.J.B.; MARCELINO, M.Q.S. et al. Aplicações da teoria da ação planejada: uma possibilidade para estudos comportamentais com agricultores familiares. Documentos, n. 212. Planaltina: Embrapa Cerrados, 2008a.
Available at: <http://www.cpac.embrapa.br/download/1252/t > Accessed on: July 26, 2010.

ROCHA, F.E.C.; CORTE, J.L.D.; SOUSA, E.S. et al. Planejamento estratégico participativo: proposta para a transferência de tecnologia da Embrapa Cerrados. Documentos, n. 263. Planaltina: Embrapa Cerrados, 2008b. Available at: <http://www.cpac. embrapa.br/download/1502/t> Accessed on: July 26, 2010.

ROCHA, F.E.C.; ALBUQUERQUE, F.J.B.; DIAS, M.R. et al. Intenção do pagamento do crédito (Pronaf): uma aplicação da teoria da ação planejada. Documentos, n. 202. Planaltina: Embrapa Cerrados, 2008c. Available at: $<$ http://www.cpac.embrapa.br/download/1294/t $>$ Accessed on: July 26, 2010.

RODRIGUES, C.A.; TEIXEIRA, A.A.; SOUZA, A.H. et al. Fatores que influenciam o sucesso de programas de IATF em gado de leite. In: SIMPÓSIO INTERNACIONAL DE REPRODUÇÃ̃O ANIMAL APLICADA, 3., 2008, Londrina. Anais... Londrina, 2008. 133-145p. Available at: $<$ http://www.geraembryo.com.br/br/trabalhos_evento. php?cod_trabalho=16> Accessed on: Apr. 19, 2011.

ROGERS, E.M. Categorizing communication channels. In: Diffusion of innovations. New York: Free Press, 1971. cap.5, p.163-206.

RUSSI, L.S. Recursos humanos na inseminação artificial em bovinos de corte. 2008. 74f. Dissertação (Mestrado em Ciência Animal) Universidade Federal de Mato Grosso do Sul, Campo Grande.

SÁ FILHO, M.F.; GIMENES, L.U.; SALES, J.N.S. IATF em novilha. In: SIMPÓSIO INTERNACIONAL DE REPRODUÇÃO ANIMAL APLICADA, 3, 2008, Londrina. Anais... Londrina, 2008. p.54-67. Available at: $<\mathrm{http} / /$ www.geraembryo.com.br/br/trabalhos_evento. php?cod trabalho=16> Accessed on: Apr. 19, 2011.

SALEM, M.B.; KHEMIRI, H. The impact of agricultural projects on cows' productivity, farmers' revenue and rural development in Tunisia. Livestock Research for Rural Development, v.20, article 70, 2008. Available at: <http://www.lrrd.org/lrrd20/5/ sale20070.htm > Accessed on: July 26, 2010.

SCHAFFNER, J.A. Rural labor legislation and permanent agricultural employment in Northeastern Brazil. World Development, v.21, p.705-719, 1993.

SOUZA, R.S. Sistemas de produção de leite: um estudo de caso sobre estrutura, tecnologia, resultados e fatores de diferenciação. Revista de Economia e Sociologia Rural, v.35, p.83-101, 1997.

THIBIER, M. The zootechnical applications of biotechnology in animal reproduction: current methods and perspectives - Review. Reproduction, Nutrition, Development, v.45, p.235-242, 2005.

TORRES-JÚNIOR, J.R.S.; MELO, W.O.; ELIAS, A.K.S. et al. Considerações técnicas e econômicas sobre reprodução assistida em gado de corte. Revista Brasileira de Reprodução Animal, v.33, n.1, p.53-58, 2009.

VILLELA, R. O desafio da expansão do CEIP. Revista DBO, n.359, p.88-92, 2010

ZUIN, L.F.S.; ZUIN, P.B.; MANRIQUE, M.A.D. A comunicação dialógica como fator determinante para os processos de ensinoaprendizagem que ocorrem na capacitação rural: um estudo de caso em um órgão público de extensão localizado no interior do estado de São Paulo. Ciência Rural, v.41, p.1-7, 2011. Available at: $<$ http://submission.scielo.br/index.php/cr/article/view/39833/4156> Accessed on: July 12, 2010. 